\title{
ERDB Research, Development and Extension Strategies for the Production of High Quality Planting Materials
}

\author{
Rafael Cadiz, Marilyn Landicho and Mylene Aparente \\ Ecosystems Research and Development Bureau, Department of Environment and \\ Natural Resources, College, Laguna 4031, the Philippines
}

\begin{abstract}
The Ecosystems Research and Development Bureau is presently conducting research, development and extension strategies for the production of high quality planting materials. The activities include the verification and assessment of existing seed stands and identification of new seed stands, as seed sources of indigenous and exotic species nationwide. Propagation protocols are being developed for some demand-driven indigenous species, and provenance cum progeny trials are being conducted for narra (Pterocarpus indicus), yemane (Gmelina arborea) and molave (Vitex parviflora). Extension activities include the establishment of a database of the information gathered by the project, capacity building, and production of brochures, leaflets and videos. It is considered that all possible mechanisms should be employed to transfer the research results effectively.
\end{abstract}

Keywords: propagation protocols, seed stands, provenance and progeny testing, data base establishment, GIS-based map

\section{RESEARCH RATIONALE AND OBJECTIVES}

Forests are renewable resources, essential for the sustenance and welfare of all terrestrial life forms. To meet future needs for wood, the forestry sector must increase production per unit area without destroying the natural resource base. Sustainable forest management is defined in the Helsinki Process as 'the stewardship and use of forests and forestland in such a way, and at a rate, that maintains their biodiversity, productivity and regenerative capacity, vitality and the potential to fulfil, now and in the future, relevant ecological, economic and social functions, at local, national and global levels, and that does not cause damage to other ecosystems' (MCPPE 1998).

In the Philippines, there is a need to establish fast-growing and high-yielding plantations to increase production of wood to meet future needs, reduce logging pressure on natural forests, and ensure biodiversity and genetic conservation of endangered, vanishing and demand-driven indigenous species (Aggangan 2000). The concern for species which can produce wood with desired properties including strength and stability needs, should also be addressed. The production of planting materials for endangered, indigenous and other forest genetic resources is a primary 
priority. Hence, a holistic strategy for wood production which at the same level prevents the eminent danger of the irreversible loss of forest genetic resources is to be adopted. Currently, the fundamental problem that needs to be addressed is the lack of supply of improved planting materials for production purposes, and for conservation of endangered indigenous and other forest genetic resources (Tolentino et al. 2002; Gregorio 2006; Cacanindin 2009). This is the rationale behind the project on the development of strategies for the production of high quality planting materials being conducted by the Research Sector of the DENR.

The project aims to: verify and gather baseline information on the status of the existing seed sources, seedlings and clonal seed orchards in the Philippines; identify new seed stands as sources of seeds of indigenous and exotic species; identify stakeholders for the possible turn-over of management, protection, collection, utilization, and distribution of seeds from the assessed and newly identified seed stands; determine the appropriate seed technology, and appropriate micro and macro propagation techniques in the production of high quality planting materials; and conduct provenance cum progeny testing of some selected species to upgrade the quality of seed sources.

\section{ACCOMPLISHMENTS}

For Activity 1 (verification and assessment of existing seed sources or seed stands of indigenous and exotic species nationwide), a total of 2543 plus trees covering 60 stands or sources were verified and assessed as of October 2008. As indicated in Table 1 , the tree species include of yemane, auri, mangium, benguet pine, narra, molave, river red gum, mahogany, pili, bakauan babae and lalaki, dao, kamagong, tindalo, white lauan, saplungan, tanguile, almon, teak, almaciga, bagras and mangasinoro.

Table 1. Existing seed stands verified and assessed

\begin{tabular}{llcc}
\hline Common name & Scientific Name & No. of seed stands & No. of trees \\
\hline Mahogany & Swietenia macrophylla & 11 & 1065 \\
Narra & Pterocarpus indicus Willd. & 7 & 206 \\
Mixed dipterocarp & & 1 & 200 \\
Yemane & Gmelina arborea & 6 & 156 \\
Pili & Canarium ovatum & 3 & 128 \\
Molave & Vitex parviflora Juss & 3 & 121 \\
Auri & Acacia auriculiformis & 3 & 117 \\
White Lauan & Shorea contorta Vid & 3 & 103 \\
Benguet pine & Pinus kesiya Royle ex. & & \\
Bagras & Gordon & 3 & 92 \\
Mangium & Eucalyptus deglupta & 3 & 78 \\
Saplungan & Acacia mangium & 3 & 58 \\
Almaciga & Hopea plagata & 1 & 38 \\
& Agathis philippinensis & 1 & 32 \\
\hline
\end{tabular}


Table 1. Existing seed stands verified and assessed (Cont.)

\begin{tabular}{llcc}
\hline Common name & Scientific Name & No. of seed stands & No. of trees \\
\hline River red gum & Eucalyptus camaldulensis & 1 & 30 \\
Tanguile & Shorea polysperma & 1 & 30 \\
Teak & Tectona grandis & 1 & 28 \\
& Rhizophora mucronata and & & \\
B. Babae and B. Lalaki & Rhizophora apiculata & 2 & 20 \\
Almon & Shorea almon & 2 & 14 \\
Mangasinoro & Shorea philippinensis & 2 & 12 \\
Dao & Dracontomelon dao & & \\
Kamagong & (Blanco) Merr. & 1 & 5 \\
Tindalo & Diospyros philippinensis & 1 & 5 \\
Total & Afzelia rhomboidea & 1 & 5 \\
\hline
\end{tabular}

For Activity 2 (identification of new seed sources or seed stands of indigenous and exotic species nationwide), a total of 918 plus trees from 33 seed sources or stands were newly identified as of October 2008 (Table 2). The 918 plus trees include species of narek, agoho. almaciga, akleng parang, bagras, molave, ipil, malapapaya, mamalis, talisay gubat, apitong, narra, falcataria, tangal, yakal, bago nangka and mangium.

Table 2. New seed stands identified and assessed

\begin{tabular}{llcc}
\hline Common name & \multicolumn{1}{c}{ Scientific Name } & No. of stands & No. of trees \\
\hline Falcata & Paraserianthes falcatarea & 3 & 302 \\
Mangium & Acacia mangium Willd & 3 & 171 \\
Molave & Vitex parviflora Juss & 5 & 75 \\
& Terminalia foetidissima & & \\
Talisay gubat & Griff & 2 & 67 \\
Mixed species & & 1 & 53 \\
Narek & Hopea cagayanensis & 2 & 44 \\
Ipil & Intsia bijuga & 2 & 43 \\
Bagras & Eucalyptus deglupta & 3 & 40 \\
Tangal & Ceriops tagal & 1 & 30 \\
Agoho & Casuarina equisetifolia L & 1 & 29 \\
Mamalis & Pittosporum pentandrum & 1 & 23 \\
\hline
\end{tabular}


Table 2. New seed stands identified and assessed (Cont.)

\begin{tabular}{llcc}
\hline Common name & \multicolumn{1}{c}{ Scientific Name } & No. of stands & No. of trees \\
\hline Malapapaya & Polyscias nodosa (Blume) & 2 & 14 \\
Dipterocarp species & Seem & 1 & 8 \\
Akleng parang & Albizia procera & 1 & 6 \\
Almaciga & Agathis philippinensis & 1 & 5 \\
& Dipterocarpus grandiflorus & & \\
Apitong & Blanco & 1 & 4 \\
Narra & Pterocarpus indicus Willd. & 1 & 2 \\
Yakal & Shorea astylosa & 1 & 1 \\
Bago & Gnetum gnemon & 1 & 1 \\
Total & & 33 & 918 \\
\hline
\end{tabular}

For Activity 3 (turn-over of management of the above-cited verified and assessed existing and newly identified seed sources or seed stands), all 14 regions are still in the process of exploratory talks with various stakeholders, including Provincial Environment and Natural Resource (PENR) officers, Community Environment and Natural Resource (CENR) officers, Protected Area Management Board officers, Local Government Units (LGUs), NGOs, academia and military reservations.

For Activity 4 (determination of appropriate propagation protocol for some indigenous species), a total of 17 species were studied, with germination and survival rate of $70 \%$ or more considered to be acceptable. These species include adelfa, bignai, dita, dungon, dangula, saraca, narek, agoho del monte, beach agoho, dao, sakat, kamuning, batikuling, Mindanao cinnamon, molave, toog and tualis. Ten species were also tested for this activity; however, they still need further refinements to meet the acceptable standard for propagation protocol. These species include narek (from cuttings where rooting is still under observation), balitbitan, bantigi, balakat, mindoro pine, payuspos, ilang-ilang, kamagong, bagalunga and mamalis. The propogation protocol developed is summarized in Table 3.

For Activity 5 (conduct of provenance and progeny trials of selected species to upgrade the quality of seed stands as source of germplasm for breeding and mass production), three regions (Regions IV-A, VII and XI) were assigned to conduct the initial provenance-trial study. The seeds for this trial came from the various research units of the regions, which were required to submit the seeds of narra, molave and yemane. Regions IV-A in Quezon National Park outplanted narra, Region VII in Bilar, Cebu outplanted molave, and Region XI in Tagum, Davao planted yemane. The locations of these activities are indicated in Figures 1 to 3. 
Table 3. Propagation protocol developed (acceptable standard of 70\% germination or survival)

\begin{tabular}{|c|c|c|c|c|}
\hline $\begin{array}{l}\text { Region } \\
\text { office }\end{array}$ & $\begin{array}{l}\text { Common name/ } \\
\text { scientific name }\end{array}$ & $\begin{array}{c}\text { Planting } \\
\text { material used }\end{array}$ & Treatment & $\begin{array}{c}\text { Percent germination } \\
\text { or survival }\end{array}$ \\
\hline $\begin{array}{l}\text { ERDB } \\
\end{array}$ & Bignai & Seeds & No pre-treatment & $82 \%$ germination \\
\hline & $\begin{array}{l}\text { Antedesma bunius } \\
\text { (L) }\end{array}$ & $\begin{array}{l}\text { Shoot tip } \\
\text { cuttings }\end{array}$ & 400 ppm NAA & $\begin{array}{l}84.7 \% \text { rooting using } \\
\text { shoot tips }\end{array}$ \\
\hline ERDB & $\begin{array}{l}\text { Dita } \\
\text { Alstonia scholaris (L) }\end{array}$ & Seeds & No pre-treatment & 92.9\% germination \\
\hline ERDB & Dungon & Seeds & Pericarp removal & 89\% germination \\
\hline & $\begin{array}{l}\text { Tarrietia sylvatica } \\
\text { (L) }\end{array}$ & & Pericarp intact & 71.5\% germination \\
\hline NCR & $\begin{array}{l}\text { Saraca } \\
\text { Saraca thaipingensis }\end{array}$ & Branchlets & $\begin{array}{l}\text { Marcots wrapped } \\
\text { with sphagnum moss } \\
\text { and treated with } \\
\text { rooting hormones }\end{array}$ & 98.6\% survival \\
\hline$\overline{\mathrm{NCR}}$ & $\begin{array}{l}\text { Adelfa } \\
\text { Nerium oleander L. }\end{array}$ & Branchlets & $\begin{array}{l}\text { Marcots wrapped } \\
\text { with sphagnum moss } \\
\text { and treated with } \\
\text { rooting hormones }\end{array}$ & $100 \%$ survival \\
\hline$\overline{\text { NCR }}$ & $\begin{array}{l}\text { Kamuning } \\
\text { Murraya paniculata } \\
\text { L. }\end{array}$ & Branchlets & $\begin{array}{l}\text { Marcots wrapped } \\
\text { with sphagnum moss } \\
\text { and treated with } \\
\text { rooting hormones }\end{array}$ & $91 \%$ \\
\hline II & $\begin{array}{l}\text { Narek } \\
\text { Hopea cagayanensis }\end{array}$ & Wildlings & $\begin{array}{l}\text { Potted in soil } \\
\text { collected from their } \\
\text { natural habitat }\end{array}$ & $89.3 \%$ \\
\hline IVA & $\begin{array}{l}\text { Batikuling } \\
\text { Litsea leytensis Merr. }\end{array}$ & Branchlets & $\begin{array}{l}\text { Marcots wrapped } \\
\text { with sphagnum moss } \\
\text { and treated with } \\
\text { rooting hormones }\end{array}$ & $\begin{array}{c}90 \% \\
\text { survival }\end{array}$ \\
\hline IVB & $\begin{array}{l}\text { Agoho del monte } \\
\text { Casuarina } \\
\text { rumpheana }\end{array}$ & $\begin{array}{l}\text { Shoot tip } \\
\text { cuttings }\end{array}$ & Hormex & $\begin{array}{c}83 \% \\
\text { survival }\end{array}$ \\
\hline $\mathrm{V}$ & $\begin{array}{l}\text { Sakat } \\
\text { Terminalia nitens }\end{array}$ & $\begin{array}{l}\text { Shoot tip } \\
\text { cuttings }\end{array}$ & No treatment & $\begin{array}{c}87.5 \% \\
\text { survival }\end{array}$ \\
\hline
\end{tabular}


Table 3. Propagation protocol developed (acceptable standard of $70 \%$ germination or survival) (Cont.)

\begin{tabular}{|c|c|c|c|c|}
\hline $\begin{array}{l}\text { Region } \\
\text { office }\end{array}$ & $\begin{array}{l}\text { Common name/ } \\
\text { scientific name }\end{array}$ & $\begin{array}{l}\text { Planting } \\
\text { material used }\end{array}$ & Treatment & $\begin{array}{l}\text { Percent germination } \\
\text { or survival }\end{array}$ \\
\hline$\overline{\mathrm{VI}}$ & $\begin{array}{l}\text { Beach agoho } \\
\text { Casuarina } \\
\text { equisetifolia Forst. }\end{array}$ & Seeds & $\begin{array}{l}\text { Seeds sown in sand } \\
\text { and garden soil } \\
\text { combination }\end{array}$ & $\begin{array}{c}82 \% \\
\text { survival }\end{array}$ \\
\hline VII & $\begin{array}{l}\text { Mindanao cinnamon } \\
\text { Cinnamomun } \\
\text { mindananse }\end{array}$ & Wildlings & $\begin{array}{l}\text { Leaves not } \\
\text { pruned }\end{array}$ & $\begin{array}{c}95 \% \\
\text { germination }\end{array}$ \\
\hline VII & $\begin{array}{l}\text { Tualis } \\
\text { Syzygium } \\
\text { longissimum (Merr) }\end{array}$ & Wildlings & No treatment & $\begin{array}{c}97.7 \% \\
\text { survival }\end{array}$ \\
\hline VIII & $\begin{array}{l}\text { Dangula } \\
\text { Teijsmanniodendron } \\
\text { ahernium (Merr) } \\
\text { Bakh. }\end{array}$ & $\begin{array}{l}\text { Wildlings } \\
\text { Shoot tip } \\
\text { cuttings }\end{array}$ & $\begin{array}{l}\text { Using mist } \\
\text { system }\end{array}$ & $\begin{array}{l}92 \% \text { survival } \\
85 \% \text { survival }\end{array}$ \\
\hline IX & $\begin{array}{l}\text { Dao } \\
\text { Dracontamelon dao }\end{array}$ & wildlings & No treatment & $\begin{array}{c}80 \% \\
\text { survival } \\
\end{array}$ \\
\hline$\overline{\mathrm{XI}}$ & $\begin{array}{l}\text { Molave } \\
\text { Vitex parviflora }\end{array}$ & $\begin{array}{l}\text { Shoot tip } \\
\text { cuttings }\end{array}$ & $\begin{array}{l}\text { Dipped with } \\
\text { ANAA }\end{array}$ & $\begin{array}{l}72 \% \text { survival (no } \\
\text { significant } \\
\text { difference with no } \\
\text { treatment) }\end{array}$ \\
\hline XIII & $\begin{array}{l}\text { Toog } \\
\text { Combretodendron } \\
\text { quadrialatum (Merr) }\end{array}$ & $\begin{array}{l}\text { shoot tip } \\
\text { cuttings }\end{array}$ & No treatment & $\begin{array}{c}80 \% \\
\text { survival }\end{array}$ \\
\hline
\end{tabular}


Mahogany

1. Poblacion, Nueva Era, llocos Norte (20 trees)

2. Experimental Forest, Banay, Nueva Viscaya (400 trees)

3. Brgy. Malicboy, Pagbilao, Quezon (114 trees)

4. Brgy. Kinabuhayan, Dolores, Quezon (95 trees)

5. Brgy. Palola, Lucban, Quezon (31 trees)

6. Camp 7, Minglanilla, Cebu (250 trees)

7. Baclay, Refo. Project, Baclay, Zamboanga del Sur (2 trees)

8. Cogon Reforestation Project, Cogon, Dipolog City (5 trees)

9. Impalutao Reforestation Project, Impasugong, Bukidnon (50 trees)

10. New Loon, Mintal, Davao City (23 trees)

11. Nabunturan ComVal (25 trees)

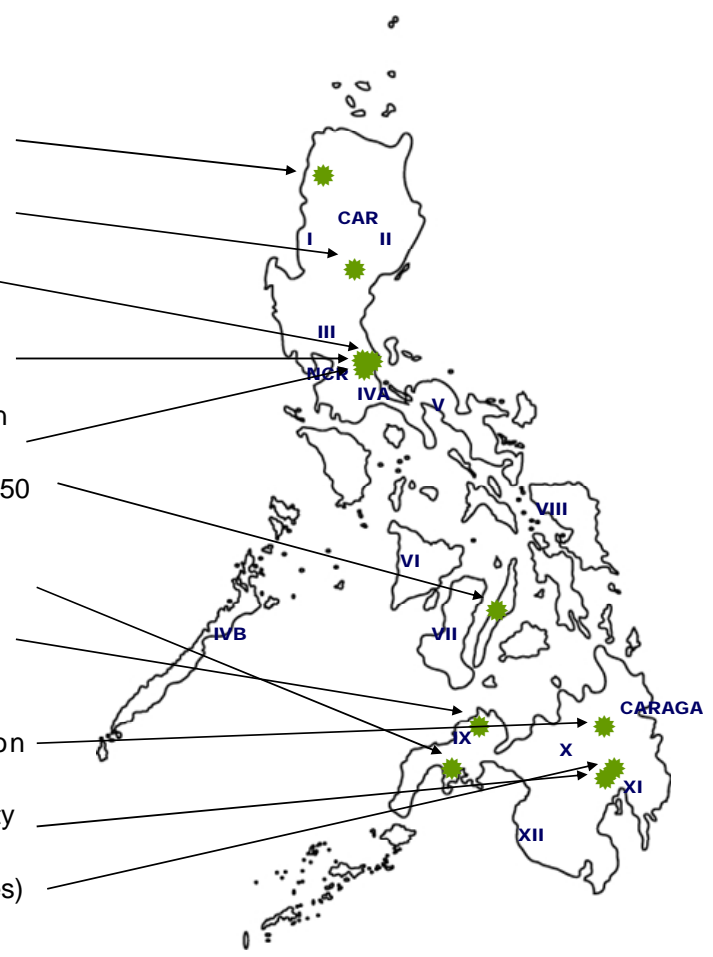

Figure 1. Planting sites for mahogany 


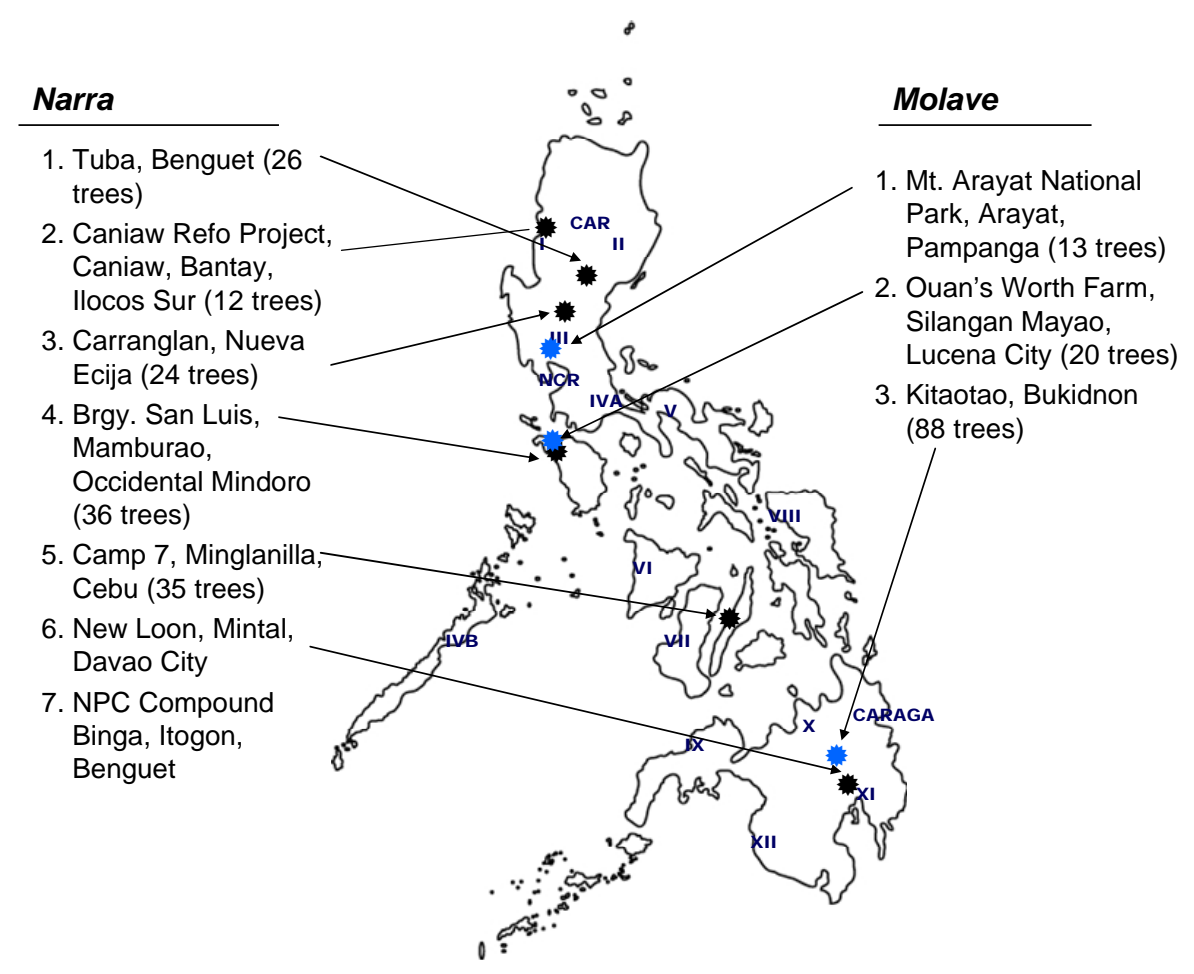

Figure 2. Planting sites for narra and molave 


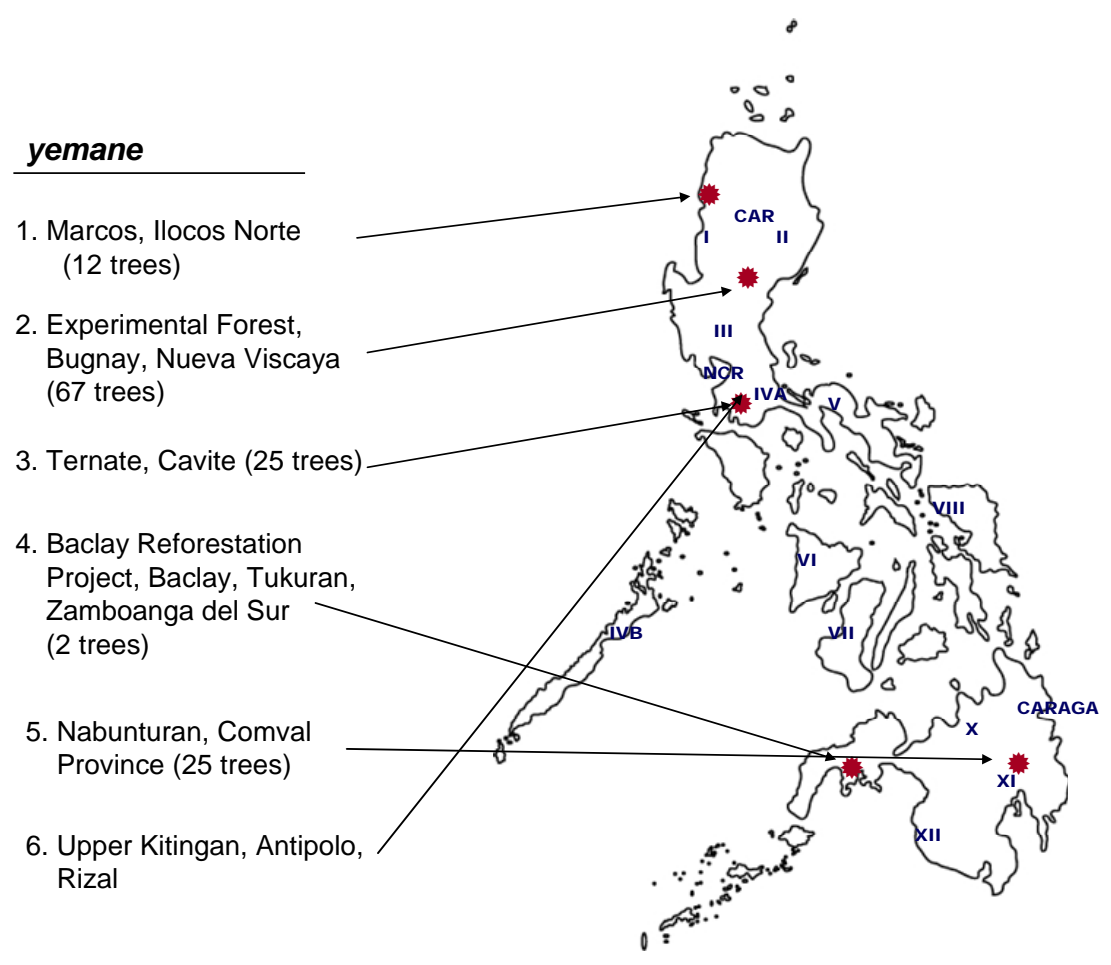

Figure 3. Planting sites for yemane

\section{EXTENSION STRATEGIES}

The target users of the results of this project include the DENR, people's organizations, LGUs, religious organizations, academia, and other organizations and individuals that need the information. The following are the extension strategies for the project:

\section{Establishment of Database}

Knowing the effectiveness of conveying information through the internet, the databasing of information gathered from the project is the successor activity of the project. All the significant information derived from the project is progressively 
uploaded to the DENR-ERDB website <http://erdb.denr.gov.ph/contact.php> to allow widespread access to information.

\section{A. Capacity Building}

Hands-on training. In clonal propagation, several hands-on training events were conducted to transfer the technology to the interested groups, including regional offices of DENR (research sector units, CENROs, PENROs), LGUs, academic institutions, NGOs and people's organizations (POs). Monitoring of the adoption of the technologies disseminated during the training events will be undertaken and carrying out another follow up training sessions will be undertaken when necessary. Gregorio (2006) and Baynes et al. (2008) both argued that frequent contacts with extension agents are necessary to ensure that stakeholders are able to adopt the technologies disseminated during training events.

Demonstration plantation. The interested farmers are brought to the plantation to show the performance of the propagated seedlings from clonal propagation. Locations of the demonstration plots include Luzon (Laguna, Cavite, Nueva Vizcaya) and Mindanao (Surigao del Sur and Davao). Demonstration plantings are effective instruments to showcase to farmers the results of new interventions. The ACIAR Smallholder Forestry project at VSU has established a number of field trials and these have been effective in disseminating silvicultural technologies to tree farmers in Leyte and Mindanao Islands (Gregorio et al. 2009)

Conduct of lectures. Conducting lectures is one of the effective methods of transferring information to the target users because of the direct contact with the audience. Questions from the target audience can easily be answered and thus immediate feedback is achieved. Several lectures have already been conducted to some LGUs, students, private plantation developers, nursery owners, religious organization and other institutions engaged in the production of high quality planting materials. The lectures conducted included topics such as seed technology, clonal nursery establishment, hedge garden establishment, maintenance and management, and macro-micro clonal propagation techniques.

\section{B. Production of Brochures or Leaflets}

The target users who do not have access to internet, television and radio can, however, be reached through leaflets or brochures in vernacular form (Gravoso et al. 2009). Some of the IEC materials produced by ERDB include 'DENR Recommends on Mass Production and Nursery Management', Research Information Series on Ecosystem (RISE), and 'Non-Mist Clonal Multiplication of Dipterocarps'.

\section{Video Production}

This strategy is costly compared to other methods and is used in a small-group gathering. However, all the stages from selection of mother trees, collection of seeds, planting, and up to the maintenance of plantation can be documented. 


\section{CONCLUDING COMMENTS}

Any research outputs would be futile if the outputs are not transferred to target clients or to interested groups and individuals. Thus, all possible mechanisms are being utilized to reach the target beneficiaries, especially the upland people who do not have easy access to technology.

\section{REFERENCES}

AGGANGAN, R.T. 2000. Tree farming in the Philippines: some issues and recommendations. In: Socio-economic Evaluation of the Potential for Australian Tree Species in the Philippines. (S.R. Harrison and J.L. Herbohn, eds). ACIAR Monograph 75, ACIAR, Canberra. pp. 33-43.

BAYNES, J. and N. GREGORIO. 2008. Nursery Training For Smallholders: an Evaluation of Two Extension Programs in the Philippines. Small-scale Forestry. 7(3-4): pp. 387-401.

CACANINDIN, D. 2009. Tree Improvement in North Eastern Mindanao. In: Proceedings of the ACIAR Seedling Enhancement Project Team Meeting Workshop (S.R. Harrison, N.O. Gregorio, A. Bosch and J. Herbohn, eds). 14 February 2009. Baybay, Leyte, the Philippines.

GRAVOSO, R., GREGORIO, N., GERONA, A. and J. GODOY. 2009. Design and Production of Instruction and Communication Materials on Best Management Practice in Forest Nurseries. In: Proceedings of the ACIAR Seedling Enhancement Project (S.R. Harrison, N.O. Gregorio, A. Bosch and J. Herbohn, eds), Team Meeting Workshop. 14 February 2009. Baybay, Leyte, the Philippines.

GREGORIO, N.O. 2006. Improving the Effectiveness of the Forest Nursery Industry in Leyte Province. PhD thesis. The University of Queensland, Brisbane.

GREGORIO, N.O., HERBOHN, J.L and J. VANCLAY. 2009. Establishing Field Trials to Promote Smallholder Forestry in the Philippines. In: Proceedings of the ACIAR Tree Farming Project: End of the Project Workshop. (S. Harrison, E. Mangaoang, A. Bosch and J. Herbohn, eds). 12-13 February 2009. Ormoc City, the Philippines

MCPPE. 1998. Annex 2 of the RESOLUTION L2-Pan-European Operational Level Guidelines for Sustainable Forest Management. In: Third Ministerial Conference on the Protection of Forests in Europe. June 1998, Lisbon, Portugal, http://www.pefc.org/internet/resources/5_1177_289_file.136.pdf. Last accessed April 2007.

TOLENTINO, E.L., CARANDANG, W.M. and J. ROSHETKO. 2002. Evaluation of Small-holder Tree Farmers Nursery: Quality Stock Production in Support of the Tree Domestication Program of the Philippines, College of Forestry and Natural Resources. UPLB, Los Banos and ICRAF. 